NBER WORKING PAPER SERIES

\title{
CONGRESSIONAL VOTE OPTIONS
}

\author{
David C. King \\ Richard J. Zeckhauser \\ Working Paper 7342 \\ http://www.nber.org/papers/w7342
NATIONAL BUREAU OF ECONOMIC RESEARCH
1050 Massachusetts Avenue
Cambridge, MA 02138
September 1999

We thank Sven Feldmann, who helped in initial stages of the paper. For helpful comments and valuable edits, we thank Miriam Avins, Sheila Burke, Rich Cooper, Mickey Edwards, Thomas Foley, Tim Groseclose, Rick Hall, Joel Kaji, John Kingdon, Keith Krehbiel, John Pratt, Philip Sharp, Helen Snively, Joe Swingle, and participants in seminars at Harvard University, Kenyon College, and at the Harvard/MIT Research Group on Positive Political Economy. Richard Zeckhauser thanks the MIT Department of Economics for its hospitality, and the National Science Foundation (grant \#7551) for support. The views expressed herein are those of the authors and not necessarily those of the National Bureau of Economic Research.

(C) 1999 by David C. King and Richard J. Zeckhauser. All rights reserved. Short sections of text, not to exceed two paragraphs, may be quoted without explicit permission provided that full credit, including $\mathbb{\odot}$ notice, is given to the source. 
Congressional Vote Options

David C. King and Richard J. Zeckhauser

NBER Working Paper No. 7342

September 1999

JEL No. C7, D7, H1

\begin{abstract}
Among political practitioners, there is conventional wisdom about the outcomes of critical and salient legislative votes. "This vote," we hear, "will either win by a little or lose by a lot." Realworld examples suggest coalition leaders purchase "hip-pocket" votes and "if you need me" pledges, which are converted to favorable votes when they will yield a victory. When the outcome is uncertain, such a process -- securing commitments in advance and calling them in if necessary -- is advantageous relative to traditional vote buying. Excess votes are not bought, nor are votes purchased for a losing effort. In effect, the leader secures options on votes. Given uncertainty, buying vote options yields two outcomes in conceivably winnable situations, one a narrow victory, the other a substantial loss. Such a distribution of outcomes is not explicable in a traditional votebuying framework. We look for evidence of this pattern -- the tracings of "if you need me pledges"-by examining all Congressional Quarterly key votes from 1975 through 1998. On these critical and salient votes, narrow victories are much more frequent than narrow losses. Furthermore, when leaders lose key votes, as predicted, they lose by bigger margins than when they win. Finally, we discuss leadership strategies for keeping "narrow wins" from unraveling into "big losses."
\end{abstract}

David C. King

Kennedy School of Government

79 JFK St.

Cambridge, MA 02138

david_king@harvard.edu
Richard Zeckhauser

Kennedy School of Government

79 JFK St.

Cambridge, MA 02138

and NBER

richard_zeckhauser@harvard.edu 


\section{Introduction}

Marjorie Margolies-Mezvinsky, a freshman Democrat from Pennsylvania, cast the decisive vote on President Clinton's 1993 budget-reconciliation bill. As the last legislator to vote on August 5, 1993, the outcome was hers to determine, and most observers expected a "no" vote. Margolies-Mezvinsky voted "yes" instead. Congressional Quarterly tells the story: "She had pledged during her campaign and even the day before the vote that she would vote against a bill that increased taxes. But Democratic leaders extracted a private promise from her to support the deficit-reduction package if her vote proved necessary to pass it" (1993 CQ Almanac, p. C39). Although it was widely predicted that the tax package would be handily defeated, President Clinton and House leaders got matters close enough to call in the option on her vote; the bill triumphed by a single vote.

In her brief career, ${ }^{1}$ Marjorie Margolies-Mezvinsky's tie-breaking vote was her moment of high drama, but year after year similar scenes unfold. Leaders build coalitions that are "close enough" to make it worthwhile to call in pledges from cross-pressured members. In most legislatures, coalition leaders rarely buy votes outright at the moment they need them in the manner that consumers buy apples and oranges. Rather, legislative leaders purchase "hip-pocket votes" or "if you need me" pledges, which are options on votes to be called in if and when needed. The "if and when" are critical; uncertainty is the primary force that makes options on votes superior to buying votes directly.

When the outcomes on highly salient legislative votes are uncertain, pundits repeat

\footnotetext{
${ }^{1}$ Margolies-Mezvinsky later lost her seat in 1994 by a not-so-slim 8,258 votes. She discusses the circumstances surrounding the vote -- using language entirely consistent with the model introduced in this paper -- in Chapter 9 of Marjorie Margolies-Mezvinsky, A Woman's Place...: The Freshmen Women Who Changed the Face of Congress (New York: Crown, 1994). Later, "as a political payback for a vote that analysts say cost her re-election," President Clinton picked her to lead his delegation to the Fourth World Conference on Women in 1995. The post paid \$117,000. See David Bauman, "Leader of Delegation to Women's Conference Says She's Woman for the Job," Denver Post, July 23, 1995, p. 5.
} 
one phrase. "This proposal," we are told, "will either win by a little, or lose by a lot." ${ }^{2}$ While it is conventional wisdom among politicians, its validity and implications have not been explored by political scientists. We sketch a picture of presidential and legislative leadership that explores how "narrow victory" coalitions get formed and why they fall apart.

President Clinton has seen his share of "narrow victory" coalitions unravel, and few were more embarrassing than the defeat he suffered on the 1994 Omnibus Crime Bill. On a critical procedural vote, White House Chief of Staff Leon Panetta boldly predicted victory ("we're going to kick some ass," was his delicate phrasing), but the president lost by fifteen votes in the House. A hoped for win became a big loss. Why? "Several members who had been willing to support the leadership if needed instead voted no when it became clear the [measure] would not pass" (Idelson \& Sammon 1994, p. 52). President Clinton did not get the vote close enough to make it worthwhile to call in the "if you need me" pledges (or vote options) he had spent the previous week securing. Once the handwriting was on the wall, we are confident President Clinton applied a fundamental rule about leading coalitions: There is no sense in exercising vote options for a losing cause.

Likewise, when coalition leaders secure sufficient votes to win, there is no reason to exercise excess vote options. Washington Democrat Norm Dicks said as much to John Kasich (R-OH) and Ron Dellums (D-CA) on September 7, 1995. Dicks' coalition, which maintained funding for the B-2 bomber, won 213 to 210 . The win was narrow, but Dicks warned his opponents not to take much comfort from getting so close, boasting that he "held six or seven votes in reserve" (Cassata 1995).

\footnotetext{
2 "Clinton Cabinet Lobbying House on Trade, United Press International, November 6, 1997; "North Carolina Lawmakers Battle Over D.C.," Washington Morning Star, October 11, 1997, pg. 5; Robert Dodge, "Senate GOP Acts Revive Fast-Track Trade Legislation; The Dallas Morning News, October 1, 1997; Meredith Oakley, "Crime Bill: Clinton Bears up for Compromise," Arkansas Democrat-Gazette, August 15, 1994, Pg. B5. By "winning" we mean that the leader's preferred outcome gets the most votes. Under united
} 
Legislative leaders put together bill-specific coalitions to win votes, though (as we will soon see) those coalitions are not necessarily "minimum winning" in the spirit of Riker (1962). We present empirical evidence of the options on votes phenomenon by analyzing presidential success at on key votes from 1975 through 1998. We use CQ votes because they are usually highly salient and closely observed by constituents, meaning members are most likely to be burdened with conflicting pressures from voters, the president, legislative leaders, special interests, and their own preferences. Furthermore, Congressional Quarterly records presidential positions for these votes, so we can readily determine whether the president's preferred position wins.

In terms of the general theory it does not matter whether our empirical focus is on the president, the speaker, or the majority leader. The literature on congressional bargaining tends to come either from a president's perspective or from a congressional leader's point of view. Both literatures capture critical elements of institutional power that the other branch does not hold. However, vote options can be employed by any leader. Indeed, a coalition leader need not have a formal leadership role at all, as the Norm Dicks example illustrates. However, the president, the speaker, and the majority leader have more "carrots" and more "sticks" available to secure vote options and to pay for exercising them when they are called.

Because it is difficult to gauge the preferences of the speaker and majority leader they often don't vote or announce a position -- our empirical tests are conducted for the president's positions, though the insights can be more generally applied. All that the story demands is a leader (or leaders) with an ability to reward and punish legislators. The literature on presidential leadership in Congress is rich (de Marchi \& Sullivan 1998; McCarty \& Poole 1995; Kernell 1993; Sullivan 1987, 1990a, 1990b; Peterson 1990, Bond \& Fleisher

governments, this "win" is usually a YES vote because the leader is more likely to control agenda access to the floor. 
1990, Edwards 1989, Covington 1987, 1988; Rivers \& Rose 1985). Likewise, insightful scholarship has taken the perspective of coalition leaders in the Congress (Groseclose \& Snyder 1996; Sinclair 1995; Snyder 1991; Fiorina \& Shepsle 1989; Baron \& Ferejohn 1989; Dodd 1983; Cooper \& Brady 1981). As valuable as these approaches are, the old saw, "win by a little, lose by a lot," has not yet been explored. Still, our vote options story should sound familiar to lawmakers, since the approach is widely used at both ends of Pennsylvania Avenue.

When deciding how to vote, legislators take account of their personal values, announced positions, the views of their constituents, and the preferences of their financial supporters (Kingdon 1989; Covington 1988). These four need not be aligned. If they are not, it is traditional to say that the legislator is cross-pressured. Then, what is in some sense their net sum will tell which way the legislator would like to vote, other factors equal. Our focus is on the effects of the additional pressures that coalition leaders bring to bear on legislators (Dodd 1983). When votes look close, clever leaders seek out cross-pressured members, whose votes might be tipped in their direction, and induce them - through compromises, side payments, and threats - to pledge their votes. Such pledges are usually contingent on their votes being needed.

A simple geometric model illustrates the qualitative features of vote options and their product, "win by a little, lose by a lot" outcomes. We do not present a formal algebraic model with proofs and mathematical appendices. Rather, we introduce the vote options concept to bring a dose of day-to-day reality to the examination of how legislative coalitions are often formed. Our empirical findings support our vote options formulation, but our findings do not exclude other complementary contributions from selective gatekeeping by committees to agenda manipulation by the Rules Committee (Groseclose \& King 1997; Dion \& Huber 1996; Krehbiel 1987; Shepsle \& Weingast 1987). We believe that our empirical findings apply 
most forcefully when there is not a strong counter-mobilization effort underway. (This is a critical difference between this paper and Groseclose \& Snyder 1996). Indeed, presidents and other coalition leaders very often "purchase" early options on votes to make countermobilization prohibitively expensive.

\subsection{Options as "Hip-Pocket" Votes and "If you Need Me" Pledges}

Former Speaker "Tip" O'Neill tells a colorful story about Leo O'Brien, a 1950s

Democratic representative from Albany, New York, in his autobiography Man of the House. ${ }^{3}$

O'Brien pledged his vote on an offshore oil bill to House Speaker Sam Rayburn (D-TX), but when newspapers found out about the promise, O'Brien had second thoughts. O'Brien went to the speaker and asked to be released from his pledge. As O'Neill tells the story, Rayburn responded,

I can certainly appreciate your situation, so here's what I'll do for you. On the day of the vote, I want to see you in the front row. Keep your eye on the doorkeeper [Fishbait Miller]. If I don't need your vote, Fishbait Miller will give you the sign and you'll be free to vote your district.

Tip O’Neill continues Leo O’Brien's Story:

It was a close fight, but in the end Sam had enough votes to win without Leo O'Brien. The funny part of it was that when Leo took his seat in the front row, he looked around and saw thirteen other guys that Sam had in his pocket in case he needed them. It wasn't just Leo. The entire front row was sitting there and waiting for the nod from Fishbait Miller. (O'Neill 1987, 134).

Sam Rayburn was an extraordinary coalition builder, and O'Neill admired Rayburn's skill at securing options on votes. There are endless stories about leaders carrying around "hip-pocket votes" to be used when needed, or otherwise released. The most common form of

\footnotetext{
${ }^{3}$ We thank Tim Groseclose for suggesting this example.
} 
a hip-pocket vote is the "if you need me" variety. As in, "This is a difficult vote for me Mr.

President, but I'll be there if you need me." (See Dodd \& Sullivan (1981), Dodd (1983) and Sinclair $(1995,244-8)$ on the securing of such pledges by party leaders.) Writing in

Congressional Odyssey, T.R. Reid describes a typical situation in which Senator Russell Long

(D-LA) was trying to put together a coalition to defeat a waterway user fee.

Eventually Long received an "if you need me" pledge from the Georgian [Democratic Senator Herman Talmadge] -- if the Senate roll call on the user charge came down to one vote, Talmadge would switch and join Long in opposition." (Reid 1980, 62)

When we read the Fishbait Miller passage to former House Speaker Thomas Foley (DWA), he nodded in agreement and smiled broadly. Foley confirmed that "if you need me" agreements are commonplace, and he said that Rayburn's innovation was getting his hippocket voters to sit in the front row where he could keep an eye on them. "The problem with some 'if you need me' pledges," cautions Foley, "is that when you need them, they sometimes can't be found until it is too late."' We will have more to say about what "until it is too late" means. For now it is enough to notice that 'options' on votes are widely known to exist, and they become operative when votes are close.

The logic of "if you need me" pledges is straightforward. Coalition leaders wish to maximize the probability that they have enough votes to win. They occasionally have to secure commitments from legislators who are either fence-sitters or low-intensity opponents, and those commitments cost something (although the currency is rarely explicit). These commitments are more like options than what economists label contingent claims (an advance purchase giving the right to a resource should a particular state of the world occur). Vote options cost something at the outset, and they cost something more to exercise. When "if you

\footnotetext{
${ }^{4}$ Interview with Speaker Thomas Foley in Cambridge, Massachusetts, April 5, 1995.
} 
need me" options are not called in (either because of a sufficient victory or a hopeless loss) they are in effect allowed to expire without exercise. Hip-pocket votes (like the ones eyeing Fishbait Miller in Man of the House) make it significantly more difficult for an opposing leader to organize, and it makes the "win by a little" outcome substantially more secure.

\subsection{Formal Theories of Vote Coalitions}

Riker's (1962) classic treatment develops the "size principle" in the context of zero-sum cooperative games. Legislators are assumed to bargain about the distribution of a fixed pie of political goodies, and the size principle predicts that minimum winning coalitions (MWCs) will form. Any additional (non-minimal) supporters must be compensated for supporting the bill, either by using side payments or by extra large benefits paid through tailoring the legislation. It is costly to extend the size of coalitions beyond a bare majority, and according to Riker, MWCs are the only rational ones to prevail. A generation of work on voting has wrestled with the assumptions or predictions of MWCs (Groseclose \& Snyder 1996; Snyder 1991; Baron \& Ferejohn 1989; Koford 1982; Shepsle 1974; Koehler 1972).

Riker's size principle says nothing about which coalitions actually form (Browne 1993, 1971). Legislators are presumed to be identical with respect to their abilities to make proposals, so any coalition constituting a bare majority might win. Moreover, once a coalition forms it can be defeated by another majority that offers a larger slice to some of the members who belonged to the former majority. Thus, any MWC in such a voting game is inherently unstable

Apart from the instability of an MWC, the size principle has been challenged by those who note that Congress heeds the norms of universalism and reciprocity (Matthews 1960). Instead of leading to minimum winning coalitions, bills are often designed to benefit a significant majority of districts or even all, and all or most legislators are included in the 
legislative bargain (Butterworth 1971; Ferejohn, Fiorina, and McKelvey 1987; Fiorina 1981;

Mayhew 1974). The first formal justification of universalism is provided by Weingast (1979).

In Weingast's model, a legislator does not know whether she will be part of an MWC, and the legislator is therefore uncertain whether a pet distributive project will be carried out. By assuring ex ante that everyone's project will be included - a universal norm - more legislators are made better off.

Universalism seems well grounded empirically. Even casual observers of Congress are aware of "Christmas tree bills," which are loaded up with goodies and pass overwhelmingly. Highway bills, like the 1998 Intermodal Surface Transportation Efficiency Act (ICE-T), provide classic examples. ICE-T authorized $\$ 217.9$ billion to be handed out over six years, and garnered large majorities in the House (337-80) and Senate (96-4). Indeed, in the $105^{\text {th }}$ House (1997-98), 771 non-procedural roll call votes passed the House, and 324 of them (42 percent) received more than 300 votes. Even in highly partisan legislatures, supermajority coalitions are common.

Groseclose \& Snyder (1996) develop a model in which supermajority coalitions may be cheaper to assemble than MWCs. They predict that MWCs will rarely occur, given organized opposition and the sequential moves by vote buyers. Their model is illuminating and we do not mean to distract from it. However, historical experience indicates that organized opposition often fails to form in legislatures precisely because one group (usually the agenda setters) secures an insurmountable number of vote options in advance. Furthermore, the evidence shows that supermajorities are common on relatively invisible votes, such as naming courthouses, and uncommon on salient issues, like changing the rules to be followed in those courthouses (Price 1978). 


\section{Buying Votes and Vote Options}

Legislators are interested in long-run policy outcomes, and they also care about how their own votes contribute to those outcomes. Consider a legislator who, drawing on her own preferences and those of her constituents, would prefer that a measure not pass. (For expositional purposes, legislators are identified as female and coalition leaders as male.) Despite her preference for voting 'no', imagine that a coalition leader supports the measure and could offer a reward, $r$, for voting 'yes.' For simplicity, assume that there is only one coalition leader. This is the typical vote buying setup so often modeled, although we reject language implying that votes are easily bought and sold with campaign contributions or other simple payoffs. The currency is complex. ${ }^{5}$.

We conduct our analysis in two steps. First, we examine the outcome when the leader is able simply to "pay" legislators to switch their votes. Straightforward vote buying is effective, whether conducted early or late, when the outcome is predictable. Second, we introduce uncertainty. We then present the reasons for using vote options, as opposed to straight vote purchases given uncertainty.

\subsection{Vote Buying, Without Options}

Lawmakers care about policy outcomes, but they must care as well about their reelection prospects, and every vote has some impact on whether one will be around for long. Beyond policy and longevity, legislators care about making a good impression on and securing the favor of leaders and committee chairs, which can translate into better assignments and more influence. These in turn can enhance favorable policies and election prospects as time rolls forward. Legislators also want to avoid missteps that might be 
exploited by opponents in future elections. Thus any vote evokes a panoply of career and reelection concerns, and legislators will take those effects into account (Kingdon 1989).

Of course, long before an issue comes to a vote, leaders and members have opportunities to shape legislation. Indeed, presidents and legislative leaders may tailor legislation to get the likely vote "close enough" to exercise the kinds of vote options discussed in the next section. ${ }^{6}$ Members draft bills, attend committee meetings, bargain with other legislators over provisions, and block agenda items. The timeframe in which they enter the policy debate and declare a position on a bill also affects their bargaining strength (BoxSteffensmeier, Arnold, \& Zorn 1997). All potential actions are weighed against each other, in a manner that depends on the likelihood of success and the degree of opposition.

Participation, issue-by-issue and bill-by-bill, varies widely (Hall, 1996). While ordinary members can engage in mutually beneficial log rolls within one bill, it is more difficult for them to exchange votes across bills, since the necessary enforcement mechanisms are weak (Weingast \& Marshall 1988). In contrast, party leaders have more durable opportunities for favor trading. They can (and do) reward or punish members for their conduct through, among other things, committee assignments, opportunities to manage bills on the floor, and access to leadership-PAC campaign money (Rohde 1991, Cox \& McCubbins 1993). Legislators can easily become cross-pressured, or in Kingdon's (1989) terms, their "field of forces" become misaligned. This is especially the case for members representing districts with heterogeneous opinions on a wide variety of issues (Fiorina 1974). We also

\footnotetext{
${ }^{5}$ We focus on carrots, positive payoffs, in this paper for simplicity, but stick-based strategies are readily incorporated into our formulation by making $r$ the total difference in payoff between the reward for a yes vote and penalty for a no vote.

${ }^{6}$ Tailoring legislation to garner more votes costs the leader. Assuming passage, he gets legislation that has been compromised away from his ideal. Leaders will constrain tailoring, recognizing the tradeoff between probability of passage and desirability of legislation. And in considering passage prospects, they will be alert to the possibility of purchasing a limited number of votes when they are necessary. Given this process, many key votes should be expected to be close. Often the leader will need to purchase a few votes to gain passage.
} 
suspect that junior legislators are more easily cross-pressured as they seek to accumulate chits from their party leaders since they have few chits in the bank, and little independent status. Party leaders might want one thing, constituents and financial supporters something else, and a member's personal preference might be different still.

Imagine how individual legislators might reap utility, or choose to vote, based on the outcome of a vote. First consider a situation where there are no payoffs or penalties from leadership. The payoffs to a legislator who is against a measure, with constituents of like mind, might appear as the "Vote NO" and "Vote YES (unpaid)" curves in Figure 1. We could draw $N$ figures for an $N$-member legislature (with different curves representing the cross pressures and preferences for each).

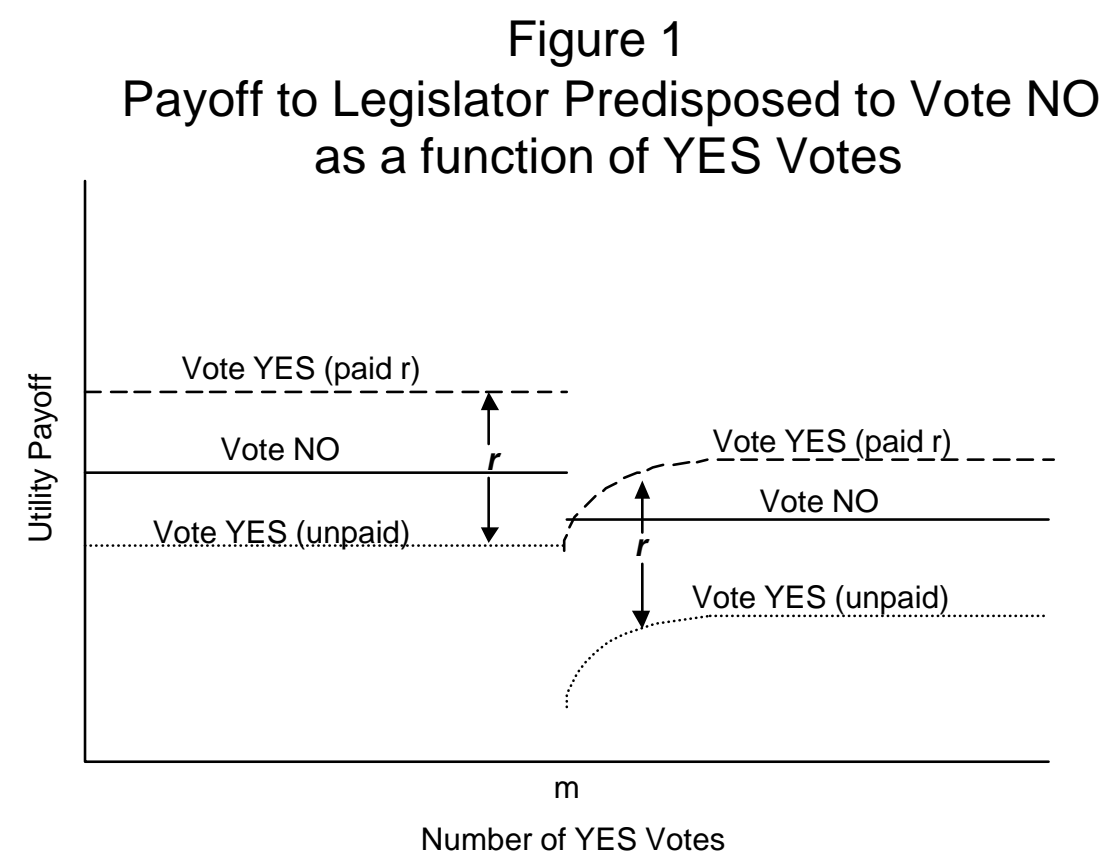

The measure passes at point $m$, where it secures a one-vote majority. (Our illustrations assume an odd number of voters.) The legislator in Figure 1 always prefers to vote against the measure rather than for - the NO curve lies above the YES (unpaid) curve and her utility is lower if it passes. 
Her guilt is greater if she votes for the measure and it passes. More important, constituents monitor their representative and punish her when she votes the wrong way (in this case if she votes YES). ${ }^{7}$ The punishment is more severe if the vote passes; constituents don't get particularly riled up when they get their preferred outcome. This combination of guilt and punishment explains why the gap between the NO and YES(unpaid) curves is greater to the right of $\mathrm{m}$, the range where the measure wins. Punishment is likely to be particularly severe - as Marjorie Margolies-Mezvinsky found out - if the legislator provides a critical vote against one's constituents' interests. Accordingly, the "Vote YES(paid $r$ )" curve drops sharply immediately to the right of $m .^{8}$

Let us say that the leader knew the measure would lose by a slight margin. If he offered $r$ for this individual's vote, the "Vote YES(paid $r$ )" curve in Figure 1 would now apply. The legislator would vote YES gladly, except in the case when she is decisive. That is because adding $r$ to the "YES(unpaid)" curve always places it above the NO curve, except at $\mathrm{m}$. She can not affect the outcome except when she is voting YES at m, or NO at m-1.

Of course not everyone gets the offer of $r$. Coalition leaders know well whom to pressure, i.e., those who will sell their vote most cheaply, and how. Pressure can be brought to bear in a variety of ways, through carrots and sticks, through present or future payoffs, through explicit commitments or informal IOUs, given to the legislator herself or to her constituents (Dodd \& Sullivan 1981). Who is induced to switch? The leader naturally goes after the individuals whose cost of switching votes is the lowest. ${ }^{9}$ Payoffs from leaders need

\footnotetext{
${ }_{8}^{7}$ For many votes, constituents may not know whether their representatives were decisive (Bianco 1994).

${ }^{8}$ When new members of Congress encounter their senior colleagues, they often hear some odd sounding advice about how to vote when cross-pressured: "Always vote for the losing side." This makes sense in the following way. If there is no "consensus in a legislator's field of forces" about how to vote (Kingdon 1989, Chapter 10), then the legislator cannot get hurt too badly by voting against something that passes or voting for something that fails. Facing constituents who wanted a measure to pass, given that it actually passed, legislators are not likely to be condemned. The same holds true for YES votes on opposed issues that fail.

${ }^{9}$ That reduces the cost of securing the votes and minimizes the efficiency cost to the legislators when he exercises the options. For the moment, we will not be concerned whether the leader price discriminates --
} 
not be explicit distributive goodies, or pork barrel projects, that lard up budgets. The more common payoff is simply a promise to be helpful on future bills, or a grant of personal benefits such as campaigning in the district, invitations to the White House, cancellation of past debts, or general credits that can be exchanged for future favors.

Leaders can roughly ascertain a legislator's willingness to have her vote bought. Perhaps there will be a wee minuet of negotiation, but once bought, votes are secure unless they are released. However insightful they may be, leaders can never know legislators' preferences and cross-pressures fully. Hence, some legislators who actually support the leader's legislation may bluff hesitancy, hoping to secure a side payment in exchange for a positive vote. De Marchi and Sullivan (1998) model such a game, looking in particular at how the game changes with repeat play, as legislators gain reputations as bluffers or straight shooters. Leaders are more willing to pay a "hesitant" legislator, the greater is the likelihood that she is a straight shooter. In their model, proven bluffers get punished, but bluffing plays no overt role in our approach. However, if a leader is or is likely to be nearing the end of his tenure, many "carrots and sticks" that could be been used depart with him. As McCarty \& Poole (1995) show for presidential vetoes and de Marchi \& Sullivan (1998) demonstrate with legislator's promises to the president, there are strong "horizon" effects. A leader vulnerable on reelection also suffers because other lawmakers believe his expected supply of rewards and punishments is diminished. Understanding how one legislator will respond, we can turn to the aggregate reaction telling how the sum total of legislators will respond.

The number of others who are voting for the measure will influence many legislators. To begin, the votes of others provide powerful cues on how one should vote, and there are strong bandwagon effects, especially on low-salience votes. The more members voting for a 
measure, the more favorable the inference. We have seen and felt this many times on the floor of legislatures: other factors equal, the number of lawmakers who would be willing to vote YES on a measure will increase with the number of other legislators who also vote YES. That is, in their personal equivalent of Figure 1, the YES(unpaid) curve cuts up through the NO curve at some point. In essence, each legislator has a reaction curve saying how she will vote as a function of the total vote. In the U.S. Congress, it is easy to respond to the votes of others, because there is a 15 to 20 minute window for voting, and legislators may vote, or even change their vote, at any time within this window (Glazer et al, 1995).

We can now add up these curves to get an "aggregate reaction function." (Note that we

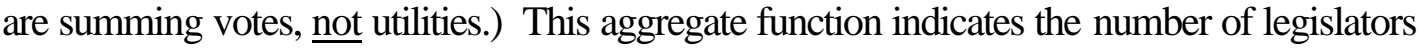
who would vote for a measure as a function of the number actually voting for it. Figure 2 shows a typical aggregate reaction function as the dark line. The function has a positive slope over most of the range because, as mentioned above, legislators learn from each other about the merits of the legislation. There are also bandwagon effects. They arise when their favorably disposed colleagues pressure them to vote for a measure, and because the potential success of a measure brings a rising tide of media and constituent attention.

The 45-degree line in Figure 2 represents potential equilibria. Along this line, the dependent variable (the number of legislators who would vote for the measure) equals the independent variable (the number of legislators actually voting for it). If the leader takes no action, the outcome rests at point $\mathrm{C}$, an $\mathrm{n}$ vote loss. Assume that the leader accurately anticipates this loss margin. He then has to decide whether he wishes to purchase n, or a few more than n, votes, or alternatively let the measure lose. If he chooses to buy $n+1$ votes, then a small win is achieved at D. 
Say that the president or House speaker would be willing to buy up to five votes to assure a bill's passage. Then, there is no chance that the measure will lose by one to nine votes. (A five-vote switch is just sufficient to overcome a nine-vote deficit.) If we think of the natural density of outcomes, a chunk is taken out of the narrow losses, and pushed over into narrow wins. In sum, the binary outcome of lose by a little or win by a lot is a product of

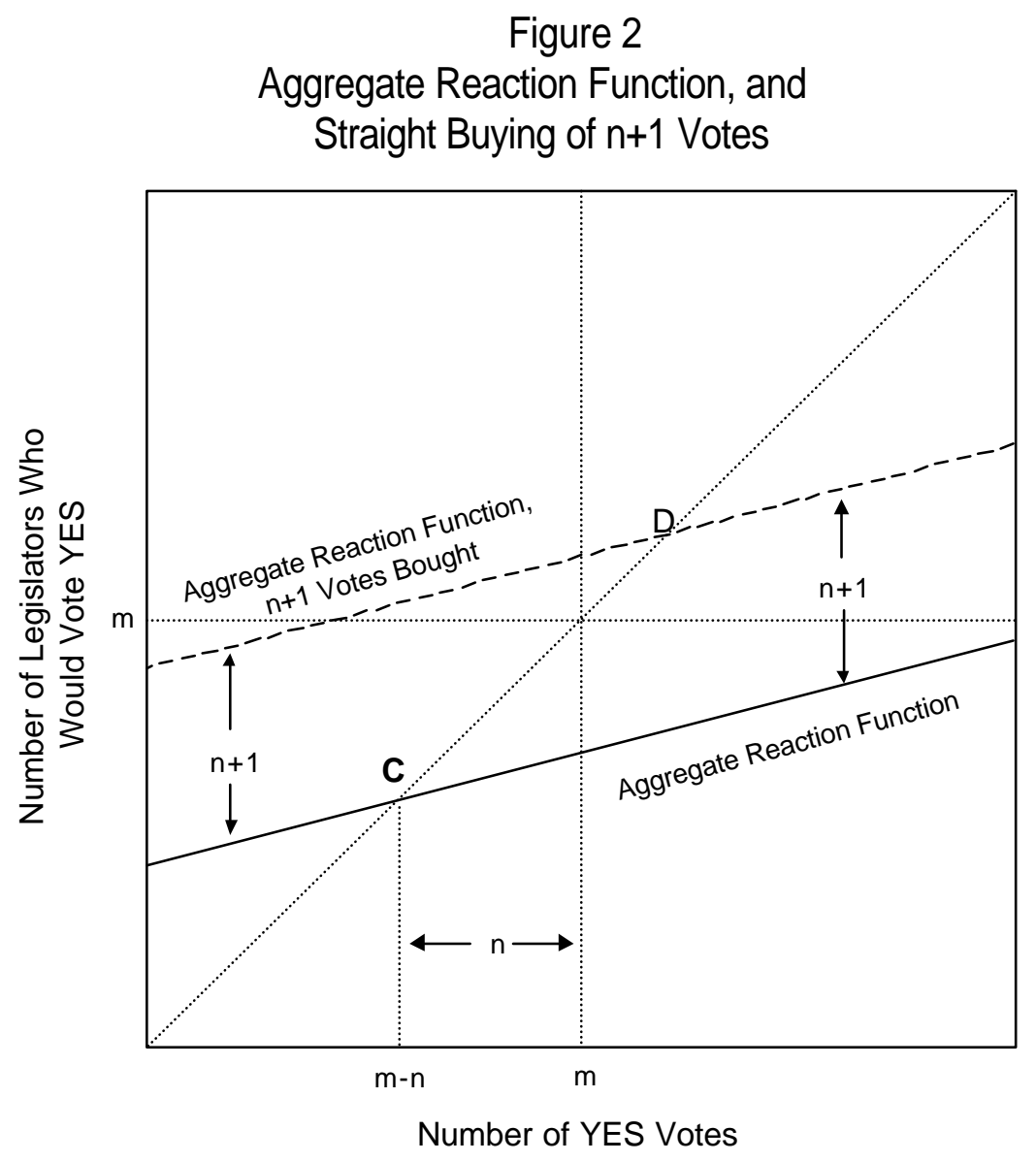

a coalition leader's strategy to count accurately and only to buy votes when needed to bring about a narrow victory.

Why would the leader buy surplus votes (i.e., $n+1$ not $n$ ), rather than just shoot for the outcome $m$ itself? First, vote counting is an imprecise practice, and it may be critical to have a safety margin in the

outcome of a vote. Second, going beyond a bare majority may also save on vote-buying costs. Cross-pressured legislators who sell their votes will get more constituent heat if they are the decisive voter, and will demand more payment for fulfilling that role. Note the dangers and inefficiencies in this straight vote-buying outcome. Given inevitable uncertainties, the leader may end up buying too many votes, or worse, paying for votes in a losing effort. That 
is, the aggregate reaction function in Figure 2 may lie higher or lower than he thought. To know how many votes to buy, he would have to know the resolution of uncertainties that only become clear as voting nears, or indeed is in progress

Why not just wait and buy when the required purchase becomes known? It may be difficult to purchase votes at the last moment, in part because it would be unseemly and more likely to be visible. In addition, the process would be hard to orchestrate and possible unstable, with opposition bidding, multiple equilibria, and so on. Late buying has an additional disadvantage. It puts the leader in a position to be extorted. This provides still a further justification for purchasing a small surplus in votes. Groseclose and Snyder (1996) similarly argue for purchasing a surplus to deter extortion, though their result depends on counter mobilization by another coalition leader. In our formulation, it may be in the individual interest of legislators to defect regardless of the presence of another coalition. Minimum winning coalitions expose fence sitters to peril, because they are more easily identifiable by their constituents.

\subsection{Vote Options}

Our exposition has been simplified by talking in terms of direct vote buying. However, there are many advantages, particularly to the leader, in securing Rayburn-style hippocket votes. Vote options allow the leader more time to shop around for votes, finding those that are cheapest, and making credible the threat to purchase from others. The greater is uncertainty - i.e., the measure could tip either way - the greater the benefit of options, for three reasons. First, final exercise may prove undesirable. Second, having lots of options in the pocket enables the leader to shift focal points. Third, accumulated options make it more difficult for others to countermobilize. 
The essential purpose of

Figure 3

Aggregate Reaction Function, and Contingent Buying of $n+1$ Votes

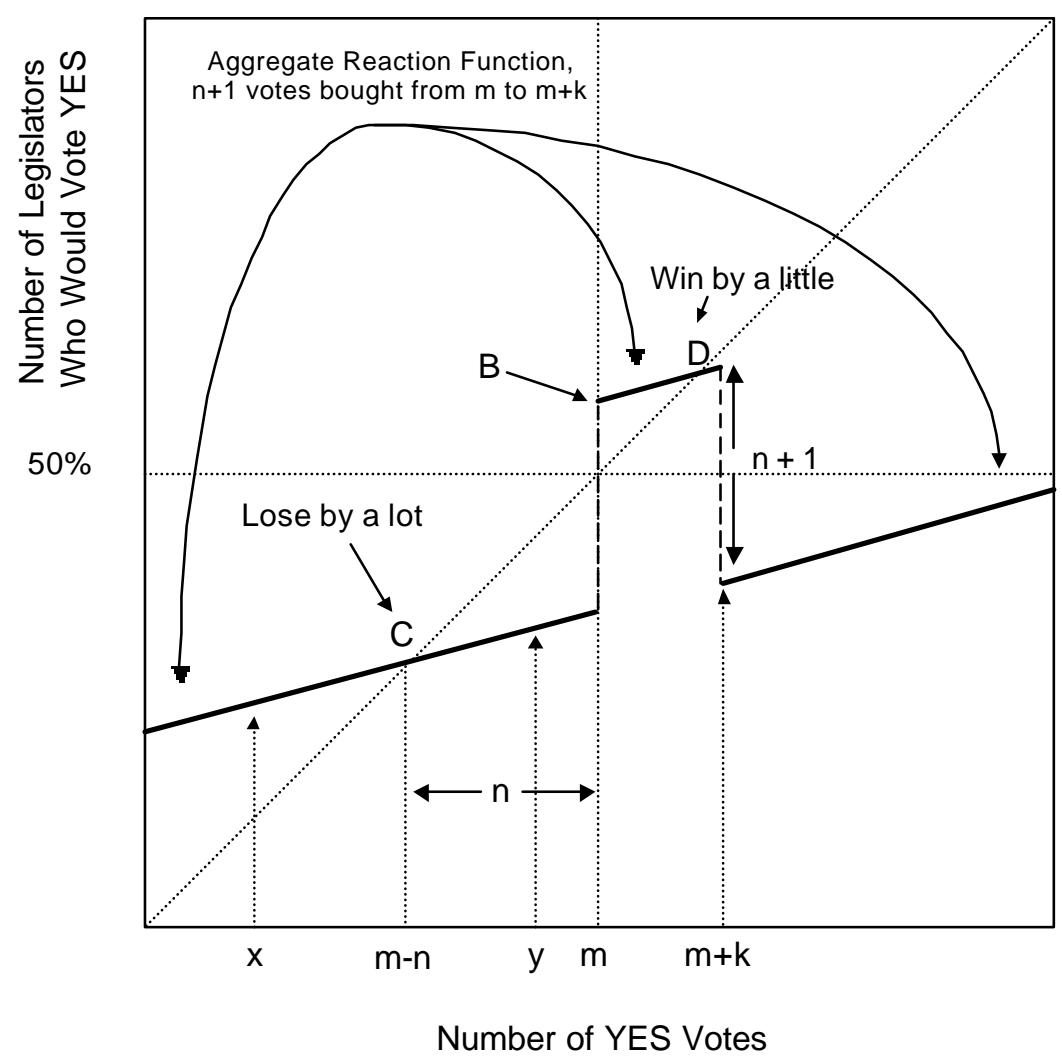

vote options is to allow leaders

to purchase votes only when

they will place the outcome in the critical range. Consider

Figure 3. Here the aggregate reaction function represents the outcome where the leader only buys votes when he discovers the outcome is in the range $m$ to $\mathrm{m}+\mathrm{k}$. Below $\mathrm{m}$ and above $\mathrm{m}+\mathrm{k}$, the vote-buying curve coincides with the unaffected reaction function.. The bare majority $\mathrm{B}$ is not stable. If it is achieved, the system will

evolve to modest victory D. If the vote falls just short of B, the situation will spiral downward to $\mathrm{C}$, a big loss. The need for a stable outcome joins imperfect information and vote-buying thrift in inducing the leader to buy more than the slimmest majority. Were the outcome to go beyond $\mathrm{m}+\mathrm{k}$, the leader would not buy any votes.

There are two stable outcomes, one at $C$ and the other at $D$. Small perturbations will not threaten these equilibria. ${ }^{10}$ Take a point $\mathrm{x}$ to the left of $C$. The reaction function there is above the $45^{\circ}$ line, and the system moves to the right, towards $C$. Similarly, a start at y,

\footnotetext{
${ }^{10}$ Stable outcomes are achieved at points where as we move right the aggregate reaction function cuts from above to below the equilibrium. Point $\mathrm{B}$, a bare majority, is not stable since it cuts from below to above.
} 
greater than $C$ but still losing, has the system move to the left. $C$ is a stable equilibrium. At it, the measure loses by a lot.

Point $D$, a modest win offering a slight safety margin, is also a stable equilibrium. To the extent that the leader can choose between (or induce the legislators to choose between) the two equilibria, assuming he would buy $n+1$ votes to assure a victory, he will prefer $D .{ }^{11}$ The leader's objective will always be to make the small victory the focal point, the outcome that individuals expect. It is no surprise that Leon Panetta, or for that matter virtually every partisan commentator in history, will state confidently "we'll win by a little" when a potentially close vote is pending. In some circumstances, the leader will not know the precise location of the reaction curve. He may seek to produce $D$, but find in the end that is not worth his while to purchase enough votes to achieve victory. If he has purchased vote options, if he has "if you need me" chits in his pocket, he merely releases these obligations.

The combination of the uncertainty as to where the aggregate reaction function lies, together with the ability to release votes when the cause is hopeless or when they would be superfluous, produces a situation before the vote where the mantra is predictive: The measure will: "Win by a little or lose by a lot."

We turn now to the mechanics of vote options. We replace the reward $r$ used earlier with a first payment, call it the option payment, $i$. The cost to the leader of exercising the option will be $e$. Assume that there is a probability $p$ that the vote will be needed. Let $\rho$ be the total payoff, equaling $i$ when the option is not exercised, and $i+e$ when it is. The expected payoff to the legislator then becomes the expected price, $E \rho=i+p e$.

It would be a mistake to roll $E \rho$ into a single price to be equivalent to our $r$ above. Consider a comparison of options, versus a contingent payment of $r$ when a vote is needed, 
where $r=10$. Say there is a $1 / x$ hance the vote will be needed. Then the leader can provide an option payment, $i=3$, and an exercise price, $e=4$. Voters who would take the contingent payoff will just accept the option, since $1 / 210)=3+1 / 24$ ). A two-part payment would never be as extreme as $r$, however. Reducing the total payment is helpful if either the leader or legislator is risk averse in levels of obligation. Smaller payments are also more discreet. Moreover, the media are less likely to be looking when the option is first purchased. A twopart payment is more enforceable than buying in advance, though less enforceable than buying when needed. ${ }^{12}$

A leader could employ three primary strategies to buy votes. He could buy them outright before the vote, he could purchase them when the vote takes place, or he could purchase options with exercise at the time of the vote. ${ }^{13}$ Effective coalition building requires

${ }^{11}$ Often the leader is able to purchase victory at a price well below his willingness to pay. Moreover, with vote options, part of the payment will have already been made, which improves the attractiveness of D relative to C.

${ }^{12} \mathrm{An}$ analogous situation has a warehouse hire an armed guard. In theory, he gets paid now to take aggressive action should a pistol-toting burglar arrive But mightn't he duck out when a truly dangerous situation arises, even if it will cost him his job? Offering a salary now, with a reward later, would be a more secure arrangement.

${ }^{13}$ We briefly assess these three strategies in relation to three criteria: administrative feasibility, efficiency, and value to the leader. Administrative feasibility is straightforward; for example it is more difficult to track down potential coalition members during a 15-minute voting period than during the hours and days leading up to a vote. Efficiency is assessed with respect to the total payoff to the leader and the legislators' votes that he might purchase. But the leader, who presumably chooses the way votes are bought, might accept some inefficiency if it gave him a higher expected net payoff, which we term value to the leader. In considering performance on these criteria, a key consideration is whether the leader can price discriminate (i.e., pay different prices for different options and/or votes). We show, in the Appendix, how securing options facilitates price discrimination.

Table F.1: Report Card for Three Coalition-Building Strategies

\begin{tabular}{|l|l|l|l|}
\cline { 2 - 4 } \multicolumn{1}{c|}{} & $\begin{array}{l}\text { Administrative } \\
\text { Feasibility }\end{array}$ & Efficiency & $\begin{array}{l}\text { Value to } \\
\text { The Leader }\end{array}$ \\
\hline Buy Votes Early & A & C & C \\
\hline Buy Votes Late & D & B+ & B \\
\hline Buy Vote Options & A- & A- & A \\
\hline
\end{tabular}


coordination and early planning, as our Fishbait Miller story should make clear. By the time the vote is underway, it may be too late to "round up the cowboys." The "buying early" strategy avoids such problems. However, this strategy falls down substantially on efficiency. Sometimes votes are purchased but the effort loses. The legislator suffers, voting against her own or her constituents' interests, but the leader reaps no compensating benefit. Hence there is a deadweight loss. In contrast, buying votes late - the implicit model in much of the MWC literature - never secures a vote that is not needed. However, it suffers from the inefficiencies of having its leader being unable to discriminate in price. ${ }^{14}$

Beyond their efficiency gains, vote options (as opposed to vote buying) offer two additional benefits to the leader: Vote options deter counter mobilization, and they enable the leader to price discriminate. The Appendix illustrates the price discrimination accomplishments of vote options. The counter mobilization benefits of vote options arise because presidents and legislative leaders have major information advantages over lawmakers. They know more about the content, timing and prospects for legislation. This informational asymmetry is greatest early on, long before an issue comes to a vote. By the time of the vote, potential counter-mobilizers know what is at stake, who is on their side, and who could be induced to switch. If all vote buying were done at the end, much, perhaps most, of the surplus would be reaped by legislators. Leaders therefore have an additional incentive to secure "if you need me" pledges early, and legislators -- finding the world highly uncertain -- will have a hard time resisting such early blandishments.

If the leader can pay a different price for different votes or options -- i.e., can price discriminate -- the value to leader and efficiency advantages of vote options vanish. Where there no concerns about Administrative Feasibility or counter mobilization, the leader would be better advised to buy whatever votes he needs at the time of the vote.

${ }^{14}$ Consider a leader who needs two votes, and who would pay 23 for a victory. The legislators he needs to turn around, label them I and II, would charge 8 and 12 respectively; simplify and assume these amounts are independent of the state of the world. However, if the leader purchases both, being unable to discriminate, he would have to pay 12 to each. The vote will be against the leader, which is inefficient since he would pay 23 for something that would cost the legislators only 20 to provide. 


\section{Evidence}

Beyond an abundance of "hip-pocket" anecdotes, we offer two types that legislative leaders purchase and exercise vote options. First, we show that possibilities exist for the strategic timing of one's vote, making the exercise of options much easier. Second, we examine 24 years of key votes to see if leaders do indeed "win by a little or lose by a lot" when trying to pass important legislation in the House and Senate, a phenomenon not predicted by traditional legislative voting models. If we find a "win by a little or lose by a lot" phenomenon, we certainly acknowledge other factors in addition to options on votes may contribute. Possible "close loss" votes may be less likely to make it to the floor. Perhaps, as John Manley (1970) noticed of Wilbur Mills, committee entrepreneurs hold back bills until they are relatively certain of success on the floor. The fundamental problem is that researchers have no way to know what the underlying distribution of expected vote margins absent vote options and agenda manipulation - might look like. A null hypothesis of symmetrically distributed outcomes around some critical "pivot point" is certainly wrong.

We turn to Congressional Quarterly Key Votes to explore vote margins in the House and Senate. Every year, Congressional Quarterly selects 20 to 30 roll call votes that are (1) a matter of controversy, (2) a matter of presidential or political power, or (3) a matter "of potentially great impact on the nation and lives of Americans" (CQ Weekly Report, Dec. 22, 1998, p. 3344). Closely contested votes are more likely to make the list. Our complete enumeration sample includes 740 key votes; for each vote we recorded tallies by party and whether the president announced a position. We focus on key votes instead of all votes because they are the ones most likely to evoke constituency interests, media attention, and leadership pressure. Furthermore, the president makes his position known on most key votes but not on many standard roll call votes. Our primary concerns, however, are over the ratio of 
narrow victories to narrow defeats and the margins of the wins and losses.

We have argued that how a legislator votes is partly a function of how other legislators have voted and their cumulative impact on the probability of a win or loss. This may be due to learning, but legislators may also need protection against constituents or the benefits of being with the leader, when needed. Voting is not meerly a weighted function of constituency, party, leadership positions, and personal interests. How one votes is often contingent on whether a measure is likely to pass or fail, and nowhere is this more clearly demonstrated than by watching the strategic timing of members' votes.

\subsection{The Time Dimension Within Votes}

Some legislatures, such as the Russian Duma, utilize simultaneous or near simultaneous votes. In the U.S. Congress, by contrast, votes are held open for 15 or 20 minutes, and changing one's vote is permissible. This time dimension within votes allows for two critical components within our theory. First, legislators can cast their ballots contingent on how others have already votes. Second, leaders have the time and the information to exercise vote options; remember Fishbait Miller's front row. This section first considers contingent voting, examining how and why some legislators play a strategic waiting game, until the outcome of the vote is assured. Speaker Rayburn used to tell incoming classes of freshmen House members, "One of the wisest things ever said was, "Wait a minute"” (Hardeman \& Bacon 1987, 428). Cautious and strategic waiting is commonplace while votes are being tallied.

The dynamics of voting are most easily seen by watching fence-sitting legislators during the course of a vote. Because legislators can vote at any time during a 15 to 20 -minute window, a vote's outcome is usually determined long before everyone has cast their ballot. Fence sitters -- or strategic waiters -- hold out until they know which side will win. Take, as 
an example, the 1990 House vote on President Bush's constitutional amendment banning flag burning. Public support for the amendment was high, although a clear majority of legislators - a greater percentage of Democrats than Republicans - had deep personal objections to the proposal (Lascher, Kelman \& Kane 1993). A cross-pressured Democrat, whose constituents supported the measure though she opposed it, could wait to vote until after the outcome was . That is, she could vote on the losing side (YES) and preserve good standing with her constituents. That is precisely what happened.

The anti flag-burning amendment needed YES votes from two-thirds (288 out of 431) of the members present on June 21, 1990, meaning that 144 NO votes would be sufficient to defeat the amendment. Proportions of Democrats and Republicans voting YES before and after the total reached 144 are shown in Figure 4. The data from this example were distilled by recording updates from C-SPAN's broadcast of the roll call. The final vote count was 254 YES and 177 NO votes, but as NOs reached the critical 144 (there were then 163 YES votes), members began applauding and exchanging high-fives, even though 124 members (or 28 percent of the chamber) had not yet cast their votes. ${ }^{15}$ Ninety-one of those 124 members (73 percent) promptly voted for the amendment, that is, for the losing side. ${ }^{16}$

\footnotetext{
${ }^{15}$ In theory, of course, the vote was determined far earlier by the proportion already voting nay, but no earlier proportion served as a focal point for both applause and vote switching.

${ }^{16}$ When a legislator is cross-pressured, there are losses whichever way she votes. However the losses from voting the wrong way - constituent blame, diminished self regard or (in relation to vote buying and options) loss of leader support - are less when one votes on the losing side.
} 
Figure 4 shows a marked difference in the ways that Democrats voted before and after the flag-burning outcome was assured, and we can conjecture the causes. For the Democrat members, the relevant leader was Speaker Thomas Foley (D-WA), who strongly opposed the amendment, although he recognized that Democrats were getting constituent pressure to

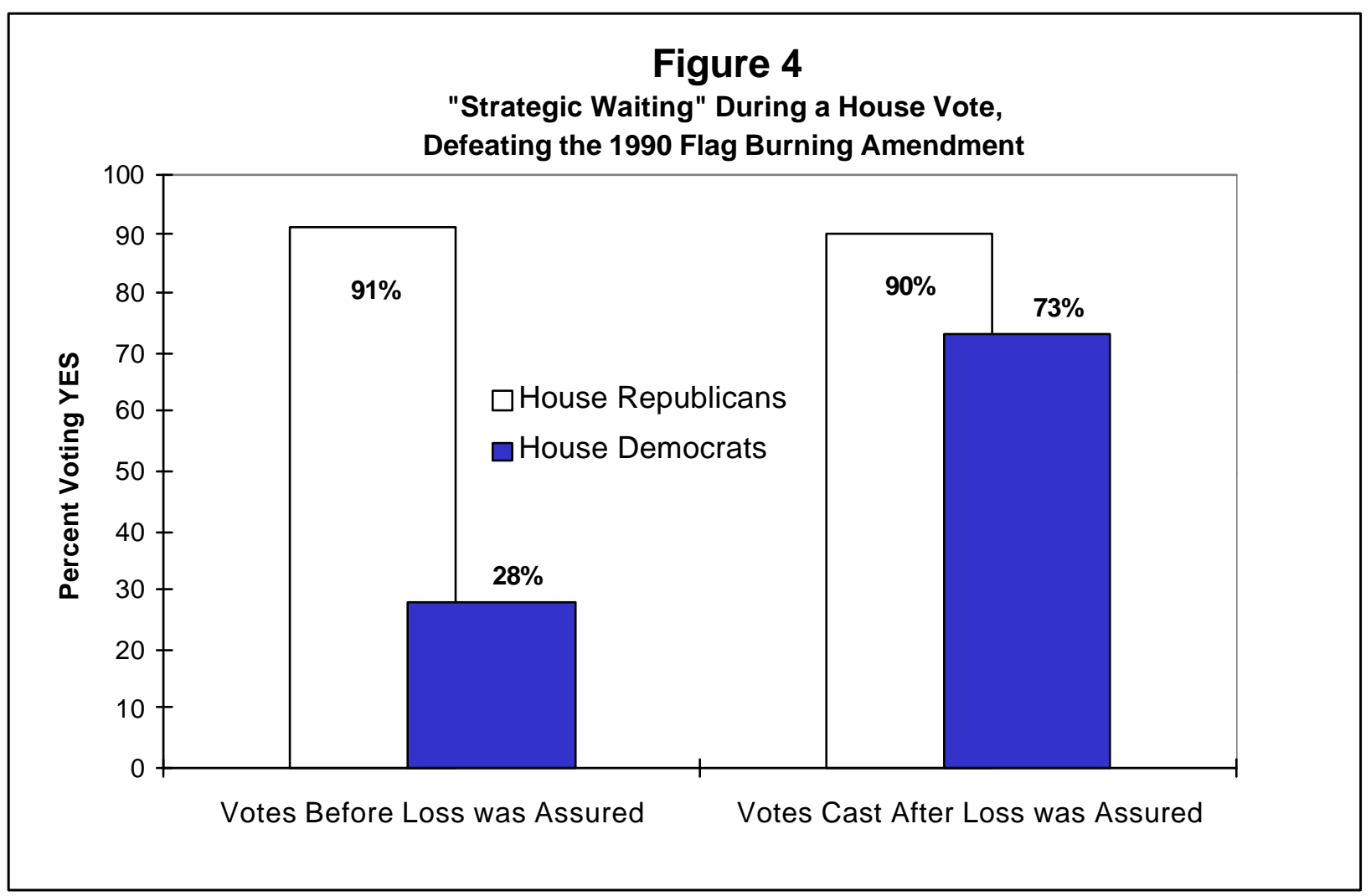

support a yes vote (1990 CQ Almanac, B10). Foley secured hip-pocket votes as insurance.

When the conditions made it clear that the amendment would fail (a Foley win), legislators were released from their pledges, and they voted overwhelmingly for the losing side, presumably to meet the wishes of their constituents. Democrats were more than two and one half times as likely to vote for the amendment once the crucial number of NO votes had been reached.

The strategic waiting dynamic shown in Figure 3 arises again and again (the key NAFTA vote in 1994 provides another example), and understanding it makes C-SPAN's 
Congress coverage even more dramatic. Legislators can hold onto their "if you need me" pledges until the last possible moment, allowing coalition leaders to "win by a little" without paying off on too many votes. There is an efficiency gain as well, as judged from the standpoint of legislators and leaders. Legislators need not suffer discomfort from voting the wrong way, when that vote is not necessary, and leaders need not compensate them for discomfort that yields no value. Strategic waiting also affects timing in the days and months before a vote (Box-Steffensmeier, Arnold \& Zorn 1997). As is true in the fifteen minutes of a House vote, legislators employ strategic waiting and signaling of their colleagues in order to maximize benefits for themselves. However, although Figure 3 is interesting in and of itself, it provides no direct evidence that narrow wins are more likely than narrow losses or that over the relevant range losses are likely to be by larger margins than wins. For that we return to CQ key votes.

\subsection{Victory Margins on CQ Key Votes}

Recall that 740 House and Senate votes have been identified as "key" by Congressional Quarterly for the 24 years from 1975 through 1998. They are usually salient votes on which members are more likely to be cross-pressured among party leaders, constituency, and policy loyalties. Yet we explore CQ Key Votes for an additional reason: the president's position is clearly marked for a majority of votes, and the president is much more likely to secure vote options on the kinds of votes in CQ's dataset. ${ }^{17}$ From 1975 through

\footnotetext{
17 Alternatively, we could have used the Speaker and Majority leader's actual voting records, but their positions may also reflect constituent-party cross-pressures. Further, the Speaker voted in only 15\% of House votes. By focusing only on presidential support for key votes, our analysis likely underestimates the prevalence of options on votes, because we do not separate times when the House and Senate leaders mobilize against the president's position.
} 
1998, presidents took positions on 475 , or 64.3 percent, of the votes. ${ }^{18}$ So that we do not lose comparability across voting conditions, we exclude votes requiring super majorities, primarily cloture votes and constitutional amendments.

The winning and losing vote margins on CQ key votes show significant support for the existence of vote options. President-led coalitions are much more likely to "win by a little" than to "lose by a little." Since 1975, the president got his preferred outcome on 59.6 percent of votes in our sample on which he took a position. But on close calls (where the president's position won by six or fewer votes in the House, for example ${ }^{19}$ ) the president won a much higher percentage. Of 34 close votes in the House, the president won 26 , or 76.5 percent. This is a substantively and statistically significant difference $(\mathrm{p}<0.02)$ from the president's baseline winning percentage. Alternatively, since 1975, a president's position lost by seven or fewer less than five votes in the House just 8 times, and all were under divided governments. Likewise in the Senate, where a one-vote margin is our metric, the president's position won by a single vote 15 times but lost by one vote just three times in 24 years.

If we exclude divided governments, under which counter-mobilization is more likely, the results prove even more compelling. Define unified government to be any instance of a president's party matching the majority party of either the House or Senate. For example, in 1982 the Senate (Republican controlled) and president (under Ronald Reagan) were unified while the House (Democrat controlled) and president were divided. Under united governments in the House, 21 key votes were decided by a margin of twenty or fewer members, and the President's position won in 19 of those votes.

\footnotetext{
${ }^{18}$ The House Speaker voted on 15.4 percent of the CQ key votes, and the Senate Majority Leader voted on 98.8 percent. The Senate Majority Leader's vote cannot be taken as a "leadership position," because the Leader only weighs in on a minority of the votes. We have tried but not succeeded in identifying a sufficiently large number of votes for which the Speaker or Majority Leader led coalitions and pressured members. We have a sea of anecdotal evidence, but nothing that can be easily matched with the CQ key votes.
} 
The "win by a little, lose by a lot" result is shown in Figure 5. The figure shows all key CQ House votes that were won or lost by 99 or fewer votes. A "win" is coded as the president's position prevailing. Nearly two-thirds of the CQ key votes were decided by a

\section{Figure 5 \\ Distribution of Vote Margins \\ CQ Key Votes in the House, 1975-1998}

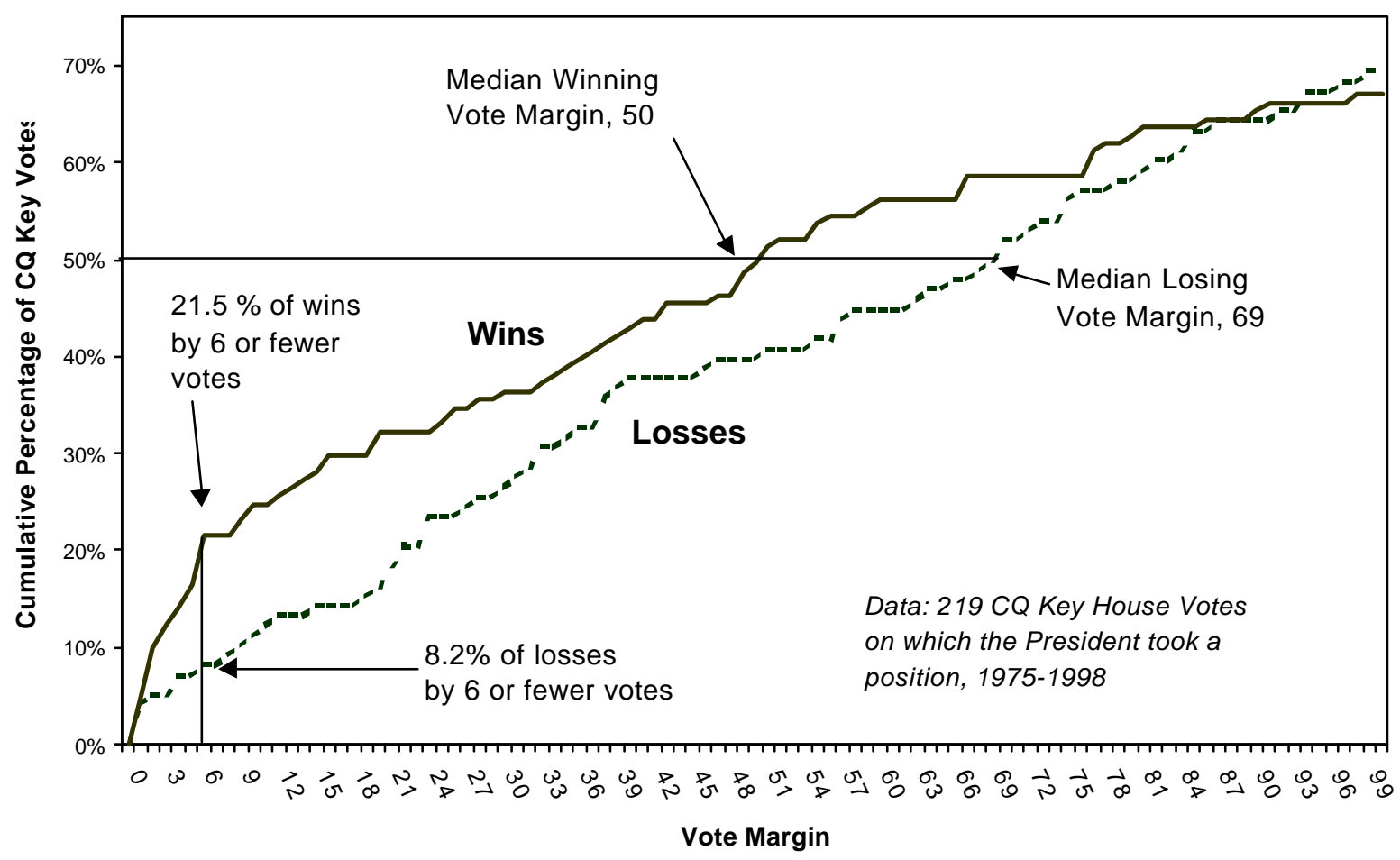

margin of 99 or less, as reflected by the cumulative percentages on the figure's vertical axis.

Figure 5 tells a clear story. The president is much more likely to win by a small margin than lose by a small margin. The maximum ratio between the cumulative distributions is found at a 6-vote margin. The maximum absolute difference is for a 20 -vote margin. Beyond that point the relative likelihood of losses mounts, until at 99 votes the two curves

\footnotetext{
${ }^{19}$ No measure either won or lost by precisely seven votes, making six a convenient cutoff. This is also the margin where the president's wins have the highest ratio relative to his losses.
} 
coincide at roughly $66.7 \%$. Note that the median loss is by 69 votes, whereas the median win is only 50 votes. Though wins are more common, losses are bigger.

Figure 5 includes several nearly unanimous wins and losses, to which our theory does not apply. Vote options are bought and exercised when the outcomes are uncertain. We cannot say, after the fact, how large a margin still allowed the outcome to be uncertain. However, about 30 percent of the president's wins were by a margin of 20 votes. At 20 votes, the win and loss curves differ significantly $(\mathrm{p}=0.002)$, and the ratio $(32.2 \%$ of the wins to $16.3 \%$ of the losses) makes it clear that some mechanism shifted a number of small losses into narrow wins.

Were there no vote options, given that presidents win more than they lose, we would expect a larger median winning margin than losing margin. The president had a .596 winning percentage across all key votes. By analogy, one would expect a basketball team with a .596 winning percentage to win big (when they win) more often than they lose big (when they lose). The empirics bear out our intuition for National Basketball Association teams in the 1999 season. For all nine teams that won at least $60 \%$ of their games, a greater percentage of their wins were by large margins than were their losses ${ }^{20}$. In the game of politics, where exercising unneeded vote options is a costly luxury, good leadership teams often try to win by a little. It makes much more sense to hold one's forces in reserve for future battles.

\subsection{Counter-Mobilization and Focal Point Control}

When Leon Panetta predicted President Clinton would narrowly win on the 1994 Omnibus Crime Bill, he was trying to signal to members that the "win by a little" equilibrium

\footnotetext{
${ }^{20}$ These nine NBA teams each won 30 or more games out of 50 in 1999 . For each, the percentage of victories by 10 or more points exceeded the percentage of losses by 10 or more points. Miami, for example, won 18 of its 33 victories $(54.55 \%)$ by 10 or more points while only 7 of its 17 losses $(41.18 \%)$ were by ten or more points.
} 
would hold. As we have noted, it is important for leaders to get cross-pressured legislators to believe that a leader's position will win, and it is in the opposition's interest to let the same members believe that the legislature will settle at the other stable equilibrium. We call this focal point control, and it should already be clear how crucial focal point control is for coalition leaders. It is also crucial for counter-mobilizers who do not have the benefits of leadership authority and agenda control.

Our attention in this analysis is directed to the strategies of leaders, but mere legislators are not without their ploys. One of the more interesting mechanisms is known as the "yellow jacket defense." 21 No matter how complicated the issues, almost everything in the House of Representatives comes down to green and red buttons. Members push green buttons for YES and red buttons for NO. Corresponding red and green lights appear next to names on a big board that is watched closely by everyone in the chamber. There is, in addition, a yellow button showing a member PRESENT but voting neither YES nor NO. Members are allowed to change their votes up to the last minute; hence yellow lights can serve tacitly to communicate and signal. ${ }^{22}$

Yellow lights send signals to other members that a coalition may be forming that could affect the focal point - converting a narrow victory into a large defeat, or conceivably vice versa, assuming the rewards are appropriate. These legislators are the most crosspressured of all, and they call out for attention. Mickey Edwards describes one situation in Behind Enemy Lines. President Reagan, and the House Republican leadership, expected all

${ }^{21}$ The term "yellow jackets" was used by Washington Post columnist David Broder in the early 1980s. An identified swarm of yellow jackets can easily tip from equilibrium to another. They also make it more expensive for the leader to induce them to vote with the leader. Say there are 15 votes needed to win, and 20 antis who would vote yes if paid 1 or more. The market-clearing price is 1 . But if they can act in unified cartel fashion, they may be able to command a price of 2 per vote, and perhaps can get that price paid to each of them.

${ }^{22}$ Indeed, 87 of the 99 state legislatures have 3-button electronic voting as well, making the "yellow jacket" option common in the states. 
Republicans to vote YES on an FY 1983 budget, but some Republicans needed a way to signal their displeasure to their leaders. Writes Edwards,

Dan Crane [R-IL] suggested that on the next amendment vote, whatever it was, we all merely vote "present" rather than "yes" or "no," and allow those strange and rare yellow lights to remain on the board throughout most of the 15 minutes of the vote... One after another we voted "present." Twenty, thirty, forty, fifty, sixty of us...

Later we switched our votes [to the way we had individually planned to vote]. The strategy worked. We drew public attention to the presence of a large dissident element within Republican ranks. (Edwards 1983, 182)

Yellow jackets need not comprise a large swarm. On close votes, a small band of members - holding out until the last possible moment to vote - can determine outcomes. While voting is open, members can wait as long as they want, or they can change their votes several times.

When former Speaker Foley told us that some hip-pocket votes cannot be found "until it is too late," he was talking about focal point control. Coalition leaders need to get their votes close enough to 50-50 that members of the coalition will think the "win by a little" equilibrium will be achieved. Members have told us of times when they rushed their supporters to vote early so that the right "signal would be sent" to undecided members. When coalitions fall along party lines, the whip systems often get activated to control the focal point. Writes Sinclair (1995, p. 247), “Occasionally getting a big vote up early will increase the probability of ultimate success. The whip system has developed an elaborate process for getting its committed members to the floor and recorded within the first several minutes of the fifteen-minute voting period." Focal point control is a significant phenomenon, widely understood and attempted by legislative leaders; the gambit is one ploy in the vote options approach. 
To sum up, our empirical findings directly support the vote options formulation: First, we found evidence that legislators "strategically wait" to cast their votes, demonstrating that how a member votes is a function of her perception of the likely outcome of the vote. Second, our approach suggests that when the likely outcome is close to 50 percent, leaders will exercise vote options, making narrow wins more common than narrow losses. We found that narrow wins are indeed more frequent than narrow losses. Third, when the likely vote outcome is not "close enough" for accumulated vote options to tilt the balance, leaders release members from their pledges, leading to not-so-narrow losses. We found that when the president loses in Congress, he loses by much larger margins than when he wins. "Win by a little or lose by a lot" indeed.

\section{Summary}

An intriguing game operates between leaders and legislators. Leaders try to find ways to exert leverage, seeking to paying the lowest cost for whatever amount of outcome shifting they can achieve, and losing graciously and without wasted expenditures when a win would be too costly. With a simple model and data from congressional votes and presidential positions, we have shown that leaders exert leverage and legislators respond. The leverage is most severe, and most worth exerting, in the neighborhood of close outcomes.

By considering roll calls with options in mind, we gain insights into strategic voting as well. The extant work on strategic or sophisticated voting looks across votes, showing (for example) that members anticipate forthcoming amendments and vote strategically (Riker 1982, Chapter 6). We argue that legislators' vote choices attempt to anticipate the likely outcome. This is clearly seen when we look at the timing of votes on the House floor. In most cases the outcome is determined before the final member pushes a green or red button, and as we saw in the flag-burning case (Figure 3), members do indeed vote strategically 
within the brief period of time they have to maneuver.

The ideal legislative leader gets the outcome he wants, when the purchase is worth it, and at the cheapest price. Many results in economics and positive political economy are of the spirit that monopolists maximize profits even though they may have never heard of a marginal revenue curve. Our story of a leader securing and selectively using vote options is not so straightforward, and play may not always be perfect. The strategies are much more complex. There are past masters like Sam Rayburn and Lyndon Johnson. But there are also those who throw away opportunities, buy votes that yield no fruit, or systematically secure too many votes or too few.

Superb vote counting is but one technical skill of a great legislative leader. A great leader also knows how many hip-pocket votes to secure, how to buy them, when to use them, and when to release them. In legislatures, "winning by a little" is a sign of effective leadership, but that delightful outcome is often just a hair's breadth away from "losing by a lot." 


\section{Appendix:}

\section{Efficiency and Price Discrimination: A Comparison of Buying Early, Buying Late, and Vote Options.}

Vote options include payments at two junctures, early and late. Thus they are a generalization of either buying votes early or buying them late, and offer advantages over either system. The example in Table A.1 illustrates gains in both efficiency and value to the leader that derive from options. Concerns about administrative feasibility are left aside.

The leader in this example can buy early, buy early contingent on the outcome, buy late, or use options. Contingent early buying allows the price to depend both on the outcome and the number of votes required. Options entail an initial payment and an exercise payment.

Our concern is with the leader, and the two legislative voters who would normally vote NO, but would be willing to switch to his side at the cheapest price. At the time early votes or vote options must be purchased, there is uncertainty. States A, B, C and D are each one fourth likely. They are differentiated by the number of vote switches required for victory, and the leader's willingness to pay for a switch. The potential switchers, I and II, do not care about the outcome per se, but are pressured by their constituents, and will lose welfare if they vote the wrong way. Independent of the state, it costs I 16 units - in some transferable currency such as dollars or political favors -- to be the decisive voter; it costs II 22.

\section{Table A.1: Vote Buying Equilibria}

\begin{tabular}{|l|c|c|c|c|c|}
\cline { 2 - 6 } \multicolumn{1}{c|}{} & State A & State B & State C & State D & $\begin{array}{c}\text { Payoff to } \\
\text { Leader }\end{array}$ \\
\hline Switches Required to Win & 1 & 1 & 2 & 2 & NA \\
\hline Value of Win to Leader & 3.99 & 20 & 40 & 120 & NA \\
\hline Cost of YES to I, II & 16,22 & 16,22 & 16,22 & 16,22 & NA \\
\hline Efficient Equilibrium & L & W & W & W & NA \\
\hline Undisturbed Equilibrium & L & $\mathrm{L}^{1}$ & $\mathrm{~L}^{1}$ & L & 0 \\
\hline Buy Early Equilibrium & $\mathrm{W}^{1}$ & $\mathrm{~W}$ & $\mathrm{~W}$ & $\mathrm{~W}$ & 2 \\
\hline $\begin{array}{l}\text { Buy Early Contingent on the } \\
\text { Outcome Equilibrium }\end{array}$ & $\mathrm{L}$ & $\mathrm{L}$ & $\mathrm{W}$ & $\mathrm{W}$ & 18 \\
\hline Buy Late Equilibrium & $\mathrm{L}$ & $\mathrm{W}$ & $\mathrm{L}$ & $\mathrm{W}$ & 20 \\
\hline Options Equilibrium & $\mathrm{L}$ & $\mathrm{W}$ & $\mathrm{W}$ & $\mathrm{W}$ & 22 \\
\hline
\end{tabular}

$\mathrm{W}=\mathrm{Win}$ for the leader. $\mathrm{L}=\mathrm{Loss}$ for the leader. A superscript ${ }^{1}$ indicates an inefficient outcome. 
We assume that regardless of the buying mechanism, the voters must be offered the same price to take the same action. Switchers must be compensated fully. If the voter is indifferent, she votes with the leader. When options are used, Fishbait Miller rules apply: voters can be committed, and the leader selects who votes with him. Efficiency is judged on total value for the three players, the two legislators and the leader.

If the leader must buy early, he will buy both votes for 22 each. If he can buy early contingent on the outcome, he will forego winning when one vote is required to achieve a majority, and pay 22 to each switcher when 2 votes are required. Either arrangement leads to an inefficiency.

Buying late, the leader will purchase a win for $\mathrm{B}$, paying 16 , and $\mathrm{D}$, paying 22 to both I and II. Buying late also proves inefficient. In State C, the measure should win, but the leader is unwilling to pay both players 22 , and price discrimination is not permissible.

An options arrangement effectively sneaks in price discrimination. The leader pays 9 to secure the option, and 4 to exercise it. He must tell in advance how and when he will exercise. In State B, he will exercise his option against I. In States C and D, he will exercise his options against both voters. It costs I $16(3 / 4)=12$ to participate; he reaps $9+4(3 / 4)=12$; hence she is just willing to sell the option on her vote. It costs II $22(2 / 4)=11$ to participate; she is paid $9+4(2 / 4)=11$, hence breaks even. The options arrangement is fully efficient, and since both sellers are indifferent about participation; all the surplus is taken by the leader.

Note, to achieve efficiency, the exercise price must be at least 4. Otherwise, the leader, unable to commit - say because States A and B are indistinguishable to the legislators - would exercise inefficiently in State A. The deadweight costs of the inefficiency created would come out of the leader's payoffs.

Expected payoffs to the leader for the four arrangements can be readily computed as: early, 2; early contingent 18, late, 20, and options, 22. 


\section{Bibliography}

Baron, David P. \& John A. Ferejohn. 1989. "Bargaining in Legislatures." American Political Science Review. 83:1181-1206.

Bianco, William T. 1994. Trust: Representatives \& Constituents. Ann Arbor: University of Michigan Press.

Bond, Jon R. \& Richard Fleisher. 1990. The President in the Legislative Arena. Chicago: University of Chicago Press.

Box-Steffensmeier, Janet M., Laura W. Arnold, Christopher J. W. Zorn. 1997. "The Strategic Timing of Position Taking in Congress: A Study of the North American Free Trade Agreement." Journal of Politics. 91:324-337.

Browne, Eric. 1971. "Testing Theories of Coalition Formation in the European Context." Comparative Political Studies. 3:391-412.

Browne, Eric. Coalition Theories: A Logical and Empirical Critique. London: Russell Sage.

Butterworth, Robert. 1971. "A Research Note on the Size of Winning Coalitions." American Political Science Review. 65:741-45.

Cassata, Donna. 1995. "B-2 Lobbying Goes to Extra Innings." CQ Weekly Report. September 9, 1995. p. 2729.

“Clinton Cabinet Lobbying House on Trade, United Press International, November 6, 1997.

Cooper, Joseph \& David W. Brady. 1981. "Institutional Context and Leadership Style: The House from Cannon to Rayburn.” American Political Science Review. 75: 411-25.

Covington, Cary. 1987. "Mobilizing Congressional Support for the President: Insights from the 1960s." Legislative Studies Quarterly. 22:77-95.

Covington, Cary 1988. "Building Presidential Coalitions Among Cross-Pressured Members of Congress." Western Political Quarterly. 41:47-62.

Cox, Gary W. \& Mathew D. McCubbins. 1993. Legislative Leviathan: Party Government in the House. Berkeley: University of California Press.

de Marchi, Scott \& Terry Sullivan. 1998. "Modeling Presidential Persuasion: Constitutional Position, Bargaining, and Dead Ducks." Manuscript. University of North Carolina at Chapel Hill. 
Dion, Douglas \& John D. Huber. 1996. "Procedural Choice and the House Committee on Rules.” Journal of Politics. 58:25-53.

Dodd, Lawrence C. 1983. "Coalition-Building by Party Leaders: A Case Study of House Democrats." Congress \& the Presidency, 10:147-168.

Dodd, Lawrence C. \& Terry Sullivan. 1981. "Majority Party Leadership and Partisan Vote Gathering: The House Democratic Whip System," in Frank H. Mackaman, ed., Understanding Congressional Leadership. Washington, DC: Congressional Quarterly.

Dodge, Robert. 1997. "Senate GOP Acts Revive Fast-Track Trade Legislation; The Dallas Morning News, October 1, 1997.

Edwards, George C. III. 1989. At the Margins: Presidential Leadership of Congress. New Haven: Yale University Press.

Edwards, Mickey. 1983. Behind Enemy Lines. Chicago: Regnery Gateway.

Fenno, Richard F. 1978. Home Style: House Members in Their Districts. Boston: Little Brown.

Ferejohn, John A., Morris P. Fiorina \& Richard D. McKelvey. 1987. "Sophisticated Voting and Agenda Independence in the Distributive Setting." American Journal of Political Science 31:169-193.

Fiorina, Morris P. 1974. Representatives, Roll Calls, and Constituencies. Lexington, Mass: Lexington Books.

Fiorina, Morris P. 1981. "Universalism, Reciprocity, and Distributive Policy-Making in Majority Rule Institutions." In John Crecine (ed.), Research in Public Policy Analysis and Management. Greenwich, CT: JAI Press, Inc.

Fiorina, Morris P. \& Kenneth A. Shepsle. 1989. "Formal Theories of Leadership: Agents, Agenda-Setters, and Entrepreneurs." In Bryan D. Jones, ed., Leadership and Politics. Lawrence, KS: University of Kansas Press.

Glazer, Amihai, Robert Griffin, Bernard Grofman, \& Martin Wattenberg. 1995. "Strategic Vote Delay in the U.S. House of Representatives." Legislative Studies Quarterly. 20:37-45.

Groseclose, Tim \& David C. King. 1997. "Committee Theories and Committee Institutions." Annual Meeting of the American Political Science Association. Washington, DC.

Groseclose, Tim \& James M. Snyder, Jr. 1996. "Buying Supermajorities." American Political 
Science Review. 90: 303-15.

Hall, Richard L.1996. Participation in Congress. New Haven: Yale University Press.

Hardeman, D. B. \& Donald C. Bacon. 1987. Rayburn: A Biography. Austin: Texas Monthly Press.

Idelson, Holly \& Richard Sammon. 1994. "Marathon Talks Produce New Anti-Crime Bill." CQ Weekly Report. August 20, 1994. pp. 2449-2454.

Kernell, Samuel. 1993. Going Public: New Strategies of Presidential Leadership. Washington, DC: Congressional Quarterly Press.

Kingdon, John W. 1989. Congressmen's Voting Decisions, 3rd edition. Ann Arbor: University of Michigan Press.

Koehler, David. 1972. "The Legislative Process and the Minimal Winning Coalition." In Richard G. Niemi \& Herbert Weisberg (eds.), Probability Models of Collective Decision Making. Columbus, Ohio: Charles E. Merrill.

Koford, Kenneth. 1982. "Centralized Vote Trading." Public Choice. 39:245-68.

Krehbiel, Keith. 1987. “Why Are Congressional Committees Powerful?” American Political Science Review. 81:929-35.

Krehbiel, Keith. 1991. Information and Legislative Organization. Ann Arbor: University of Michigan Press.

Krehbiel, Keith. 1998. Pivotal Politics: A Theory of U.S. Lawmaking. Chicago: University of Chicago Press.

Lascher, Edward L., Jr., Steven Kelman \& Thomas J. Kane. 1993. "Policy Views, Constituency Pressure, and Congressional Action on Flag Burning." Public Choice. 76:79-102.

Manley, John F. 1970. The Politics of Finance: the House Committee on Ways and Means. Boston: Little, Brown.

Margolies-Mezvinsky, Marjorie, with Barbara Feinman. 1994. A Woman's Place...: The Freshmen Women Who Changed the Face of Congress. New York: Crown.

Matthews, Donald R. 1960. U.S. Senators and Their World. Raleigh, NC: University of North Carolina Press. 
Matthews, Donald R. \& James A. Stimson. 1975. Yeas and Nays: Normal Decision-Making in the U.S. House of Representatives. New York: Wiley.

Mayhew, David. 1974. Congress: The Electoral Connection. New Haven: Yale University Press.

Mayhew, David. 1991. Divided We Govern: Party Control, Lawmaking, and Investigations, 1946-1990. New Haven: Yale University Press.

McCarty, Nolan M. \& Keith T. Poole. "Veto Power and Legislation: An Empirical Analysis of Executive and Legislative Bargaining from 1961 to 1986." Journal of Law Economics and Organization. 11:282-312.

McKelvey, Richard. 1976. "Intransitivities in Multidimensional Voting Models and Some Implications for Agenda Control." Journal of Economic Theory. 12:472-82.

"North Carolina Lawmakers Battle Over D.C.," Washington Morning Star, October 11, 1997, pg. 5.

Oakley, Meredith. 1994. “Crime Bill: Clinton Bears up for Compromise,” Arkansas Democrat-Gazette, August 15, 1994. Pg. B5.

O'Neill, Thomas P. with William Novak. 1987. Man of the House: The Life and Political Memoirs of Speaker Tip O'Neill. New York: Random House.

Peterson, Mark A. 1990. Legislating Together: The White House and Capitol Hill from Eisenhower to Reagan. Cambridge: Harvard University Press.

Price, David. 1978. "Policymaking in Congressional Committees: The Impact of Environmental Factors.” American Political Science Review. 72:548-74.

Reid, T.R. 1980. Congressional Odyssey: The Saga of a Senate Bill. New York: Freeman.

Riker, William H. 1962. The Theory of Political Coalitions. New Haven: Yale University Press.

Riker, William H. 1982. Liberalism Against Populism. Prospect Heights, IL: Waveland.

Rivers, Douglas \& Nancy L. Rose. 1985. "Passing the President's Program: Public Opinion and Presidential Influence in Congress." American Journal of Political Science. 29:183-96.

Rohde, David W. 1991. Parties and Leaders in the Postreform House. Chicago: University of Chicago Press. 
Shepsle, Kenneth A. 1974. "On the Size of Winning Coalitions." American Political Science Review. 68-505-18.

Shepsle, Kenneth A. 1979. "Institutional Arrangements and Equilibrium in Multidimensional Voting Models." American Journal of Political Science. 32:27-59.

Shepsle, Kenneth A., \& Barry R. Weingast. 1987. "The Institutional Foundations of Committee Power." American Political Science Review. 81:85-104

Sinclair, Barbara. 1995. Legislators, Leaders, and Lawmaking. Baltimore: Johns Hopkins University Press.

Snyder, James M., Jr. 1991. "On Buying Legislatures." Economics and Politics. 3:93-109.

Sullivan, Terry. 1987. "Presidential Leadership in Congress: Securing Commitments." In Mathew D. McCubbins \& Terry Sullivan (eds.), Congress: Structure and Policy. New York: Cambridge University Press.

Sullivan, Terry. 1990a. "Explaining Why Presidents Count: Signaling and Information." Journal of Politics. 52:939-92.

Sullivan, Terry. 1990b. "Bargaining with the President: A Simple Game and New Evidence." American Political Science Review. 84:1067-94.

Weingast, Barry R. 1979. "A Rational Choice Perspective on Congressional Norms." American Journal of Political Science. 23:245-62.

Weingast, Barry R. \& William J. Marshall. 1988. "The Industrial Organization of Congress." Journal of Political Economy. 96:132-63. 